\title{
Pengaruh Sediaan Dekok Daun Zaitun (Olea europaea L.) terhadap Kadar Glukosa Darah pada Tikus Putih Galur Wistar (Rattus norvegicus) Galur Wistar Jantan yang Diinduksi Aloksan
}

\author{
Ashfi Millati ${ }^{1}$, Yenni Bahar ${ }^{2}$, Titik Kusumawinakhyu ${ }^{2}$ \\ ${ }^{I}$ Mahasiswa Fakultas Kedokteran, Universitas Muhammadiyah Purwokerto \\ ${ }^{2}$ Dosen Fakultas Kedokteran, Universitas Muhammadiyah Purwokerto
}

Email: titikkusumawinakhyu@gmail.com

\begin{abstract}
Blood glucose is a sugar in the blood that is formed from carbohydrates and stored as glycogen in the liver and skeletal muscles. Diabetes mellitus is a set of metabolic disorders in the presence of hyperglycemia due to damage to insulin secretion, insulin work or a mixture of both. The olive leaf (Olea europaea L.) has rich phenol content. Polyphenols in olive leaf (Olea europaea L.), especially oleuropein, are thought to have hypoglycemic effects with their mechanisms that are capable of affecting insulin release, have the effect of increasing glucose uptake into cells. To analyze the effect of olive leaf (Olea europaea L.) on the fasting blood glucose level of wistar (Rattus norvegicus) male rodent white rat induced alloxan. Method used is pretest and post test contol group design with repeat ANOVA test and continued with post hoc test, if anova not requirement, then used Friedman test to know the existence of difference. 1) There is influence of olive leaf steaming on fasting blood glucose level of wistar (Rattus norvegicus) male rats of alloxan-induced rats, 2) There is a tendency of increase of fasting blood glucose level of white rat of male wistar strain in control group; 3) Fasting blood glucose in male rats of male wistar strains in the group given herbs of olive leaf plant in the treatment of dose I (540 mg / 200gram BB rat), dose II (1080 mg / 200gram BB rat), and dose III (2160 mg / 200 gram BB rat), 4) There was more decrease in treatment of dose III compared to treatment group dose I and dose II.There is difference (influence) of olive leaf (Olea europaea L.) to the fasting blood glucose level of wistar (Rattus norvegicus) male rats which are induced alloxan.
\end{abstract}

Keywords: Blood Glucose, Olive Leaves, Aloksan.

\section{Abstrak}

Glukosa darah merupakan gula dalam darah yang terbentuk dari karbohidrat dan disimpan sebagai glikogen di hati dan otot rangka. Diabetes Melitus merupakan sekumpulan gangguan metabolik dengan adanya hiperglikemia akibat kerusakan pada sekresi insulin, kerja insulin atau campuran keduanya. Daun zaitun (Olea europaea L.) memiliki kandungan kaya fenol. Polifenol pada daun zaitun (Olea europaea L.), khususnya oleuropein diduga meiliki efek hipoglikemi dengan mekanismenya yaitu kemampuan untuk mempengaruhi pelepasan insulin, memiliki efek untuk meningkatkan uptake glukosa ke dalam sel. Menganalisis pengaruh seduhan daun zaitun (Olea europaea L.) terhadap kadar glukosa darah puasa tikus putih galur wistar (Rattus norvegicus strain wistar) jantan yang diinduksi aloksan. Metode yang digunakan dalam penelitian ini adalah pretest and post test contol group design dengan uji yang digunakan adalah repeat ANOVA, jika salah satu syarat untuk uji ANOVA tidak terpenuhi, maka dilanjutkan dengan uji Friedman untuk mengetahui adanya perbedaan. 1) Terdapat pengaruh seduhan daun zaitun terhadap kadar glukosa darah puasa tikus putih galur wistar (Rattus norvegicus strain wistar) jantan yang diinduksi aloksan, 2) Terdapat kecenderungan peningkatan kadar glukosa darah puasa tikus putih galur wistar jantan pada kelompok kontrol sebesar $103 \mathrm{mg} / \mathrm{dl}, 3)$ Terdapat penurunan kadar glukosa darah puasa tikus putih galur wistar jantan pada kelompok yang diberikan tanaman herbal seduhan daun zaitun pada perlakuan dosis I (540 mg/200 gram BB tikus), dosis II (1080 mg/200 gram BB tikus), maupun dosis III (2160 mg/200 gram BB tikus), 4). Terdapat penurunan sebesar $207 \mathrm{mg} / \mathrm{dl}$ pada perlakuan dosis III dibandingkan kelompok perlakuan dosis I maupun dosis II. Terdapat pengaruh seduhan daun zaitun (Olea europaea L.) terhadap kadar glukosa darah puasa tikus putih (Rattus norvegicus) galur wistar jantan yang diinduksi aloksan.

Kata Kunci: Glukosa Darah, Daun Zaitun, Aloksan. 


\section{PENDAHULUAN}

Glukosa darah merupakan gula dalam darah yang terbentuk dari karbohidrat dan disimpan sebagai glikogen di hati dan otot rangka ${ }^{1}$. Kadar glukosa darah merupakan salah satu faktor yang mempengaruhi kelancaran kerja tubuh dan menjadi energi untuk sebagian besar fungsi sel dan jaringan. Pembentukan energi juga memiliki jalur alternatif yaitu melalui metabolisme asam lemak, namun jalur tersebut kurang efisien dibandingkan dengan pembakaran langsung glukosa, hal tersebut dapat mempengaruhi kadar glukosa ${ }^{2}$. Diabetes mellitus merupakan sekumpulan gangguan metabolik dengan adanya hiperglikemia akibat kerusakan pada sekresi insulin, kerja insulin atau campuran keduanya ${ }^{3}$.

Pengobatan untuk penderita diabetes mellitus banyak yang menggunakan obat konvensional namun memiliki resiko, dengan adanya efek samping dan komplikasi yang tinggi, sehingga perlu pemanfaatan tanaman yang memiliki kemampuan atau khasiat tertentu untuk diabetes mellitus, salah satu tanaman di indonesia yang memiliki efek untuk menurunkan kadar glukosa darah adalah daun zaitun (Olea europaea L.). Daun zaitun (Olea europaea L.) memiliki kandungan kaya fenol yang bermanfaat bagi kesehatan manusia ${ }^{4}$.

Kandungan fenol tersebut khususnya adalah oleuropein. Oleuropein diduga berperan untuk memberikan efek hipoglikemi, antihipertensi, antioksidan, antiinflamasi, kardioprotektif, dan yang mendukung terapi obesitas. Polifenol pada daun zaitun (Olea europaea L.), khususnya oleuropein diduga meiliki efek hipoglikemi dengan mekanismenya yaitu kemampuan untuk mempengaruhi pelepasan insulin, memiliki efek untuk meningkatkan uptake glukosa ke dalam sel, dengan adanya kemampuan hipoglikemia pada daun zaitun, maka dapat membantu penderita diabetes melitus untuk menggunakan pengobatan tradisional dengan efek samping yang minimal ${ }^{5}$.

Ekstrak olive oil diambil dari bagian buahnya, sedangkan banyak orang menganggap bagian daunnya

Induksi aloksan di lakukan hari ke delapan setelah aklimatisasi. Dosis aloksan yang digunakan adalah 125 $\mathrm{mg} / \mathrm{kgBB}$ yang dilarutkan dalam akuades steril 2 ml/aloksan kemudian diinjeksikan ke tikus secara intraperitoneal ${ }^{10}$.

Pengambilan darah tikus dilakukan pada hari ke 3 setelah di induksi aloksan. Pengambilan darah setelah tikus berpuasa selama 8 jam. Pengambilan darah melalui sinus orbitalis, karena relatif mudah dan hanya tidak digunakan atau di buang, padahal dalam penelitian mengenai daun zaitun, dikatakan bahwa konsentrasi oleuropein di dalam daun zaitun juga tinggi seperti buah zaitun $^{6}$. Kandungan senyawa oleuropein mencapai 2,44 gram / 100 gram bobot daun kering ${ }^{7}$.

Pernyataan tersebut membuat penulis tertarik untuk mengetahui apakah terdapat pengaruh seduhan daun zaitun (Olea europaea L.) terhadap kadar glukosa darah puasa tikus putih galur wistar (Rattus norvegicus) jantan yang diinduksi aloksan, apabila dapat dibuktikan bahwa oleuropein dalam daun zaitun (Olea europaea L.) dapat mempengaruhi gula darah puasa pada tikus yang diinduksi aloksan, maka seduhan daun zaitun (Olea europaea L.) dapat menjadi pedoman oleh manusia sebagai pengobatan diabetes mellitus.

\section{METODE}

Penelitian berupa eksperimental laboratorik rancangan penelitian pretest and post test contol group design. Sampel yang digunakan pada penelitian ini adalah tikus putih galur wistar (Rattus norvegicus) jantan yang diperoleh dari Laboratorium Farmasi Universitas Muhammadiyah Purwokerto dengan besar sampel pada masing-masing kelompok terdiri dari enam ekor tikus putih galur wistar (Rattus norvegicus) jantan $(n=6)$ yang dibagi menjadi empat kelompok.

Pada penelitian ini ditetapkan jumlah sampel yang digunakan pada setiap kelompok percobaan yaitu sebanyak 6 ekor tikus putih galur wistar (Rattus norvegicus) jantan, dan cadangan 4 ekor tikus pada masing-masing kelompok yang diperoleh dengan rumus estimasi kematian yaitu $10 \%$ dari total sampel 24 ekor tikus putih galur wistar (Rattus norvegicus) jantan ${ }^{8}$.

Tikus diaklimatisasi selama satu minggu sebelum perlakuan dan hanya diberi air putih dan diet pakan standar tikus berupa Pelet AD $\mathrm{II}^{\circledR}$ secara ad libitum, jumlah makanan yang diberikan $5 \mathrm{mg} / 100 \mathrm{gBB} /$ ekor/hari, selama aklimatisasi semua tikus di timbang berat badannya9.

membutuhkan sedikit peralatan. Mata dan kesehatan tikus tidak terpengaruh jika teknik pengambilannya dilakukan dengan benar. Tikus dipegang dengan cara ibu jari dan operator memberikan tekanan pada vena jugularis di bagian caudal mandibula. Cara tersebut dapat membendung aliran kembali darah vena dari sinus orbitalis. Kemudian jari telunjuk operator menarik bagian dorsal kelopak mata kebelakang sehingga akan menimbulkan sedikit exopthalmus ${ }^{10}$. 
Daun zaitun dikeringkan sehingga menjadi teh. Pembuatan seduhan teh daun zaitun (Olea europaea L.) menggunakan metode dekok. Metode dekok yang digunakan mirip dengan metode pembuatan infus, yaitu menggunakan dua panci yang saling bertumpuk. Panci bagian atas di isi daun zaitun (Olea europaea L.) yang telah dihaluskan dan dikeringkan, sedangkan panci bagian bawah di isi zat penyarinya, yaitu air yang langsung kontak dengan api. Panci bawah akan memanaskan air hingga suhu $100^{\circ} \mathrm{C}$, namun panas yang di dapatkan oleh panci atas hanya bersuhu $90^{\circ} \mathrm{C}^{11}$.

Dosis dikonveriskan dari manusia ke tikus, yaitu didapatkan dosis $540 \mathrm{mg} / 200$ gram BB Tikus, 1080 mg / 200 gram BB Tikus, 2160 mg / 200 gram BB Tikus dilarutkan dalam $150 \mathrm{ml}$ air kemudain diberikan secara peroral untuk tikus sebanyak $2 \mathrm{ml}^{12}$.
Data yang diperoleh dari hasil penelitian diuji analisis statistik menggunakan aplikasi pengolah data. Data yang diperoleh diuji normalitasnya dengan uji Saphiro-Wilk dan uji homogenitas Levene. Jika data berdistribusi normal serta homogen $(p>0,05)$, maka dilanjutkan dengan uji analisis varian dua arah (repeat ANOVA) dengan taraf kepercayaan 95\% sehingga dapat diketahui apakah perbedaan yang diperoleh bermakna atau tidak. Dipilih uji ANOVA karena data berskala kategorik-numerik dan uji analisis dua arah (repeat ANOVA) karena data berpasangan (pretest and post test only contol group design). Uji ANOVA akan dianggap bermakna bila $p<0,05$. Jika salah satu syarat untuk uji ANOVA tidak terpenuhi, maka dilakukan uji Friedman untuk mengetahui adanya perbedaan.

\section{HASIL}

Tabel 1 Hasil pengukuran kadar glukosa darah puasa tikus putih galur wistar jantan

\begin{tabular}{cccc}
\hline Kelompok & $\begin{array}{c}\text { Sebelum } \\
\mathrm{mg} / \mathrm{dl}\end{array}$ & $\begin{array}{c}\text { Sesudah } \\
\mathrm{mg} / \mathrm{dl}\end{array}$ & $\begin{array}{c}\text { Sebelum-Sesudah } \\
\mathrm{mg} / \mathrm{dl}\end{array}$ \\
\hline $\mathrm{K} 1$ & 187.33 & 222.33 & 103.00 \\
$\mathrm{~K} 2$ & 281.00 & 254.17 & 27.83 \\
$\mathrm{~K} 3$ & 294.00 & 177.17 & 116.83 \\
$\mathrm{~K} 4$ & 508.17 & 238.17 & 270.00 \\
\hline
\end{tabular}




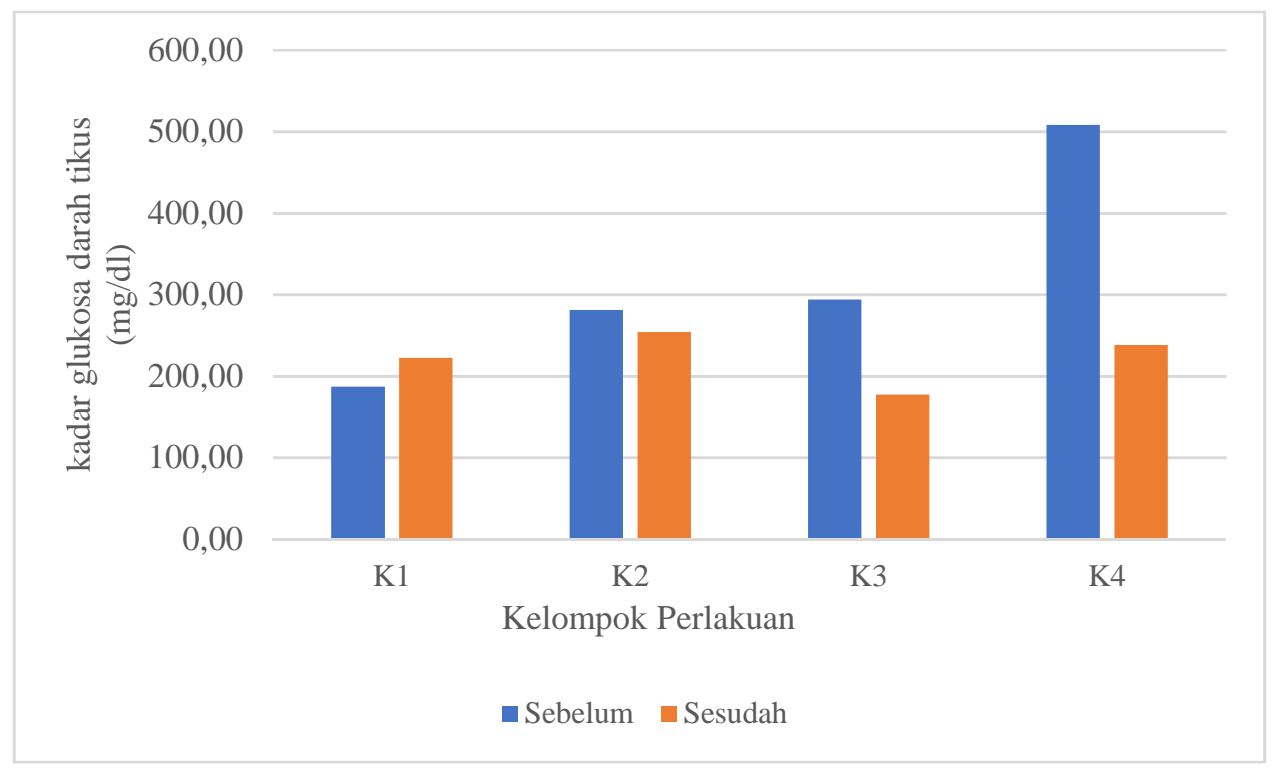

Gambar 1. Diagram batang rata-rata kadar glukosa darah puasa tikus putih galur wistar jantan

Keterangan :

K1: kelompok kontrol (diinduksi aloksan dan tanpa seduhan daun zaitun)

K2: kelompok perlakuan I (diinduksi aloksan dan seduhan daun zaitun dosis I $540 \mathrm{mg} / 200$ gram BB tikus)

K3: kelompok perlakuan II (diinduksi aloksan dan seduhan daun zaitun dosis II $1080 \mathrm{mg} / 200$ gram BB tikus)

K4: kelompok perlakuan III (diinduksi aloksan dan seduhan daun zaitun dosis III $2160 \mathrm{mg} / 200$ gram BB tikus)

Sebelum: kadar glukosa darah puasa tikus putih galur wistar jantan sebelum perlakuan (pretest)

Sesudah: kadar glukosa darah puasa tikus putih galur wistar jantan setelah Perlakuan (posttest)

Diagram diatas menunjukkan adanya perbedaan rata-rata glukosa darah puasa tikus putih galur wistar jantan pada dua kali pengukuran. Hasil pengukuran sebelum perlakuan menunjukkan rata-rata kadar glukosa darah puasa yang mencapai $>126 \mathrm{mg} / \mathrm{dl}$ setelah diinduksi aloksan. Pengukuran sesudah perlakuan menunjukkan rata-rata kadar glukosa darah puasa masing-masing kelompok terlihat rata-rata terlihat lebih rendah, namun rata-rata kadar glukosa darah puasa kelompok kontrol terlihat hasil lebih tinggi dari hasil sebelum perlakuan.
Kelompok kontrol terdapat peningkatan kadar glukosa darah puasa sebanyak $103 \mathrm{mg} / \mathrm{dl}$, sedangkan pada kelompok perlakuan yang diberi tanaman herbal dekok daun zaitun terlihat kelompok perlakuan dosis III (K4) didapatkan hasil lebih rendah dibandingkan dengan kelompok perlakuan dosis I (K2) maupun dosis II (K3).

\section{Uji Normalitas}

Uji normalitas menggunakan Shapiro-Wilk terdapat satu kelompok dengan hasil 0,045 $(p<0,05)$ maka distribusi data tidak normal, sedangkan setelah melalui uji kesamaan varians terdapat data yang tidak homogen, maka tidak dapat menggunakan uji repeated ANOVA sehingga penelitian ini menggunakan uji statistik alternatif, yaitu uji Friedman.

\section{Uji Friedman}

Tabel 2 Hasil Uji Friedman

\begin{tabular}{cccc}
\hline $\mathrm{N}$ & Chi-square & $\mathrm{df}$ & Asymp. Sig \\
\hline 6 & 14.600 & 3 & 0,002 \\
\hline
\end{tabular}

Berdasarkan hasil uji Friedman didapat nilai asymp sig sebesar $0.002<0.05$, maka dapat disimpulkan terdapat perbedaan (pengaruh) seduhan daun zaitun (Olea europaea L.) terhadap kadar glukosa darah puasa tikus putih galur wistar (Rattus norvegicus) jantan yang diinduksi aloksan. 
Tabel 3 Nilai ranking rata-rata nilai gula darah puasa tikus putih galur wistar jantan

\begin{tabular}{ccccc}
\hline Group & $\begin{array}{c}\text { Kontrol } \\
(\mathrm{K} 1)\end{array}$ & $\begin{array}{c}\text { Dosis I } \\
(\mathrm{K} 2)\end{array}$ & $\begin{array}{c}\text { Dosis } \\
\text { II } \\
(\mathrm{K} 3)\end{array}$ & $\begin{array}{c}\text { Dosis } \\
\text { III(K4) }\end{array}$ \\
\hline $\begin{array}{c}\text { Mean } \\
\text { Rank }\end{array}$ & 2.33 & 1.17 & 2.50 & 4.00 \\
\hline
\end{tabular}

Tabel ranks di atas didapat nilai mean rank tertinggi adalah dosis III (K4), hal ini menunjukan bahwa dosis III (K4) atau perlakuan dosis III (K4) sangat signifikan berpengaruh dalam penurunan kadar glukosa pada tikus putih galur wistar

\section{PEMBAHASAN}

Pada penelitian ini sebelum pemberian sediaan dekok daun zaitun, tikus diinduksi dengan aloksan dosis $125 \mathrm{mg} / \mathrm{kgBB}$ tikus yang diinjeksikan satu kali secara intraperitoneal. Tiga hari setelah induksi aloksan, kadar glukosa darah puasa tikus pada sebagian kelompok perlakuan belum mengalami hiperglikemi hingga mencapai $126 \mathrm{mg} / \mathrm{dl}$, hal ini tidak sesuai dengan penelitian yang menjelaskan bahwa dosis tersebut dapat meningkatkan kadar glukosa darah puasa tikus 3 hari setelah induksi aloksan ${ }^{13}$. Pada penelitian lain juga menyatakan bahwa 3 hari setelah injeksi aloksan dengan dosis aloksan $125 \mathrm{mg} / \mathrm{kgBB}$ juga dilaporkan dapat meningkatkan kadar glukosa darah puasa tikus mencapai $>126 \mathrm{mg} / \mathrm{dl}^{14}$.

Pada metodologi penelitian, peneliti menggunakan total pemberian dosis aloksan 125 $\mathrm{mg} / \mathrm{kgBB}$ tikus akan tetapi pada proses penelitian terdapat sebagian kelompok perlakuan yang kadar glukosa darah puasanya belum mencapai $>126 \mathrm{mg} / \mathrm{dl}$, maka diberikan penambahan dosis aloksan sebesar 25 $\mathrm{mg} / \mathrm{kgBB}$ tikus yang diinjeksikan secara intraperitoneal pada semua kelompok 3 hari setelah induksi aloksan dosis pertama $125 \mathrm{mg} / \mathrm{kgBB}$ tikus, sehingga total pemberian dosis pada penelitian ini adalah 150 $\mathrm{mg} / \mathrm{kgBB}$ tikus. Hal tersebut sesuai dengan penelitian yang menggunakan pemilihan dosis $150 \mathrm{mg} / \mathrm{kgBB}$ dilaporkan mampu menginduksi tikus mengalami Diabetes Melitus tipe II. Pengunaan dosis kurang dari $150 \mathrm{mg} / \mathrm{kgBB}$ intraperitoneal dikhawatirkan belum adekuat untuk menginduksi tikus menjadi Diabetes ${ }^{15}$.

Dosis aloksan berkisar antara $100-200 \mathrm{mg} / \mathrm{kgBB}$. Dosis $130 \mathrm{mg} / \mathrm{kgBB}$ tergolong dosis sedang, sedangkan dosis $160 \mathrm{mg} / \mathrm{kgBB}$ tergolong dosis tinggi. Pemberian dosis ringan hingga sedang belum mampu menginduksi tikus mengalami Diabetes Melitus, sehingga pada penelitian ini menggunakan total pemberian dosis aloksan $150 \mathrm{mg} / \mathrm{kgBB}$ agar tikus mengalami Diabetes Melitus tipe II dan kadar glukosa darah puasanya mencapai $>126 \mathrm{mg} / \mathrm{dl}^{15,17}$.

Pada penelitian ini terdapat empat kelompok yang terdiri dari kelompok kontrol (K1), kelompok perlakuan dosis I (K2) $540 \mathrm{mg} / 200 \mathrm{gram}$ BB tikus, kelompok perlakuan dosis II (K3) $1080 \mathrm{mg} / 200$ gram BB tikus, dan kelompok perlakuan dosis III (K4) 2160 $\mathrm{mg} /$ gram BB tikus.

Kelompok kontrol (K1) pada penelitian ini merupakan kelompok yang sebelum perlakuan diberikan induksi aloksan untuk meningkatkan kadar glukosa darah puasa tikus, namun saat perlakuan tidak diberikan sediaan dekok daun zaitun. Kerusakan yang ditimbulkan oleh penginduksian aloksan yaitu terapat dua mekanisme kerja, yaitu secara selektif dapat menghambat sekresi insulin dengan merusak sel $\beta$ pankreas dengan cara kompetisi selektif up take senyawa dengan perantara GLUT 2, sedangkan mekanisme kerja yang kedua yaitu induksi pembentukan Reactive Oxygen Species (ROS) yang dapat menghasilkan nekrosis selektif sel $\beta$ pankreas ${ }^{16,19}$.

Ketika terjadi kerusakan tersebut pada tikus yang diinduksi aloksan, kemudian tidak diberikan terapi maka akan terus terjadi kerusakan dan hal tersebut menyebabkan peningkatan kadar glukosa darah puasa tikus. Peningkatan kadar glukosa darah puasa tikus yang dilihat pada diagram gambar IV.2 diperoleh peningkatan sebanyak $103 \mathrm{mg} / \mathrm{dl}$.

Sedangakan pada kelompok perlakuan dosis I (K2), II (K3) dan III (K4) terjadi penurunan kadar glukosa darah puasa setelah diberi sediaan dekok daun zaitun. Kelompok perlakuan yang paling signifikan terdapat pengaruh sediaan dekok daun zaitun yaitu pada kelompok perlakuan dosis III (K4) $2160 \mathrm{mg} / 200$ gram BB tikus mengalami penurunan sebanyak 207 $\mathrm{mg} / \mathrm{dl}$. Penurunan tersebut lebih rendah dibandingkan dengan kelompok perlakuan dosis I (K2) $540 \mathrm{mg} / 200$ gram BB tikus sebanyak $27,83 \mathrm{mg} / \mathrm{dl}$ maupun dosis II (K3) $1080 \mathrm{mg} / 200$ gram BB tikus sebanyak 116,83 $\mathrm{mg} / \mathrm{dl}$.

Penurunan kadar glukosa darah puasa pada semua kelompok perlakuan yang diberikan sediaan dekok daun zaitun dapat disebabkan oleh kandungan daun zaitun yaitu oleuropein. Kandungan oleuropein yang terdapat dalam daun zaitun memiliki konsentrasi 
senyawa oleuropein mencapai $2.44 \mathrm{~g} / 100 \mathrm{~g}$ bobot kering daun ${ }^{7}$.

Pemberian dosis $2160 \mathrm{mg} / 200$ gram BB tikus maka konsentrasi senyawa oleuropein pada daun zaitun menjadi lebih besar dibandingkan dengan dosis I dan dosis II. Senyawa oleuropein yang terdapat pada daun zaitun antara $1 \%$ dan $14 \%$ sedangkan buah zaitun adalah $0,005 \%$ dan $0,12 \%$. Oleuropein pada daun zaitun memiliki senyawa turunan, salah satunya oleuropeosid yang memiliki efek antihiperglikemik pada hewan yang diinduksi diabetes dengan aloksan. Penelitian tersebut menyimpulkan bahwa senyawa ini dapat meningkatkan ambilan glukosa pada jaringan perifer hewan percobaan ${ }^{20}$.

Sesuai dengan penelitian yang menjelaskan bahwa penurunan kadar glukosa darah pada tikus yang mengalami hiperglikemi dapat disebabkan oleh mekanisme kerja oleuropein yaitu dapat memberikan efek untuk mempengaruhi pelepasan insulin, memiliki efek untuk meningkatkan uptake glukosa ke dalam sel dan hambat pembentukan Reactive Oxygen Species (ROS). ${ }^{5}$ Kerusakan yang terjadi pada keadaan Diabetes Melitus tipe II tersebut dapat menyebabkan peningkatan kadar glukosa darah puasa pada tikus yang diinduksi aloksan dosis $150 \mathrm{mg} / \mathrm{kgBB}$ intraperitoneal, sehingga dengan diberikan sediaan dekok daun zaitun yang memliki kandungan oleuropein dengan mekanisme kerjanya mempengaruhi pelepasan insulin dan meningkatkan uptake glukosa ke dalam sel dapat menurunkan kadar glukosa darah puasa tikus yang sebelumnya mengalami hiperglikemi ${ }^{5}$.

Mekanisme kerja aloksan yang kedua adalah induksi pembentukan Reactive Oxygen Species (ROS) yang dapat menghasilkan nekrosis selektif sel $\beta$ pankreas. ${ }^{16}$ Hal tersebut dapat meningkatkan kadar glukosa darah puasa tikus, kemudian tikus yang telah mengalami peningkatan kadar glukosa darah puasa dengan diinduksi aloksan dosis $150 \mathrm{mg} / \mathrm{kg}$ BB tikus, diberikan sediaan dekok daun zaitun dengan mekanisme kerjanya yaitu hambat pembentukan Reactive Oxygen Species (ROS). ${ }^{5}$

Daun zaitun dengan metode sediaan dekok memberikan pengaruh sebagai pilihan untuk menurunkan kadar glukosa darah. ${ }^{21}$ Daun zaitun merupakan salah satu tanaman herbal yang memliki khasiat untuk pengobatan Diabetes Melitus, hal tersebut sesuai dengan penelitian ini, tikus yang mengalami hiperglikemia dapat mengalami penurunan kadar glukosa darah puasa setelah diberikan sediaan dekok daun zaitun ${ }^{4}$.

\section{SIMPULAN}

1. Terdapat pengaruh seduhan daun zaitun terhadap kadar glukosa darah puasa tikus putih galur wistar (Rattus norvegicus strain wistar) jantan yang diinduksi aloksan.

2. Terdapat kecenderungan peningkatan kadar glukosa darah puasa tikus putih galur wistar jantan pada kelompok kontrol.

3. Terdapat penurunan kadar glukosa darah puasa tikus putih galur wistar jantan pada kelompok yang diberikan tanaman herbal seduhan daun zaitun pada perlakuan dosis I $(540 \mathrm{mg} / 200$ gram BB tikus), dosis II (1080 mg/200gram BB tikus), maupun dosis III (2160 mg/200 gram BB tikus).

4. Terdapat penurunan lebih banyak pada perlakuan dosis III dibandingkan kelompok perlakuan dosis I maupun dosis II.

\section{SARAN}

1. Perlu dilakukan penelitian lebih lanjut terhadap dosis seduhan daun zaitun yang lebih efektif dari dosis $2160 \mathrm{mg} / \mathrm{dl}$ yang tidak menyebabkan hipoglikemi.

2. Perlu dilakukan penelitian lebih lanjut tentang senyawa tunggal oleuropein pada daun zaitun sebagai fitofarmaka untuk terapi Diabetes Melitus.

\section{DAFTAR PUSTAKA}

1. Lee, Joyce le Fever. (2007). Pedoman Pemeriksaan Laboratorium dan diagnostik. Dialihbahasakan oleh: Sari Kurnianingsih. Jakarta: EGC

2. PERKENI. (2011). Konsensus Pengelolaan dan Pencegahan Diabetes Melitus Tipe 2 di Indonesia. Jakarta: PERKENI

3. Salindeho, A., Mulyadi., Rottie, J. (2016). Pengaruh Senam Diabetes Melitus Terhadap Kadar Gula Darah Penderita Diabetes Melitus Tipe 2 di Sanggar Senam Persadia Kabupaten Gorontalo. ejournal Keperawatan (e-Kp). 4(1)

4. Hudaib,M., Mohammad, M., Yasser, B., Rabab,T., Mohammad,Y., Mustafa,A., Talal,A. (2008). Ethnopharmacological Survey of Medicinal Plants In Jordan, Mujib Naturereserve And Surrounding Area. Elsevier, 120 (2008) 6371

5. Vogel, P., Machandoz, I.P., Garavagliaz, J., Zani, T.V., Souza, D., Boscon, S.M. (2015). Polyphenols benefits of olive leaf (Olea europaea L) to human health. Nutricion Hospitalaria, 31 (3), 1427-1433

6. Sari, A.P. (2016). Karakter vegetatif tanaman zaitun (Olea europaea L) pada kondisi tanam 
yang berbeda serta konsentrasi oleuropein dan asam askorbat pada daunnya.

7. Jemai H, El-Feki A, Sayadi S.2009. Antidiabetic And Antioxidant Effect Of Hydroxytyrosol And Oleuropein From Olive Leaves In AlloxanDiabetic Rats. J Agric Food Chem. 57:87988804.

8. Dahlan, Sopiyudin. (2011). Statistik Untuk Kedokteran dan Kesehatan Edisi 5.Jakarta: Salemba Medika.

9. Haqim, R. (2015). Pengaruh Seduhan Daun Talok (Muntingia calabura) Terhadap Kadar Glukosa Darah Tikus Putih Jantan (Rattus norvegicus) Diabetes Melitus yang Diinduksi Streptozotocin

10. Tama,C., Dewi, E., Ibrahim, R. (2012). Pengaruh pemberian Ekstrak Gracilaria verrucosa terhadap kadar Glukosa darah Tikus Putih (Rattus norvegicus)

11. Cahyadi, A. (2013). Daya Tolak Infusa Daun Pandan Wangi (Pandanus amaryllifolius Roxb.) Terhadap Peletakan Telur Nyamuk Aedes Spp. Skripsi. Fakultas Kedokteran Universitas Tanjungpura Pontianak

12. American Diabetes Association. (2010). Diagnosis and Classification of Diabetes Mellitus. Diabetes Care Vol.33: hal 562-569.

13. Benny, W., Sugiyanta., Purwandhono, A. (2014). Efek Ekstrak Buah Pare (Momordica charantia) dan Metformin terhadap Kadar Glukosa Darah Tikus Wistar yang Diinduksi Aloksan: Perbandingan Terapi Kombinasi dan Terapi Tunggal

14. Prameswari, O.M., Widjanarko, S.B. (2014). Uji Efek Ekstrak Air Daun Pandan Wangi Terhadap Penurunan Kadar Glukosa Darah dan Histopatologi Tikus Diabetes Melitus. Jurnal Pangan dan Agroindustri

15. Firdaus, E.M. (2014). Efek Kayu Manis "Cinnamomum cassia" Terhadap Kadar Glukosa
Darah, Berat Badan Dan Trigliserida Pada Tikus Jantan Strain Sprague dawley Yang Diinduksi Aloksan. Skripsi. Jakarta. Fakultas Kedokteran dan Ilmu Kesehatan Universitas Islam Negeri Syarif Hidayatullah Jakarta

16. Lenzen, S. (2008). The Mechanisms of Alloxan and Streptozotocin-Induced Diabetes. Diabetalogia. Germany: Institute of Clinical Biochemistry, Hannover Medical School. 51: 216-226

17. Arif, S.P. (2016). Studi Pengaruh Variasi Dosis Terapi Infusa Pekat Buah Pare (Momordica charantia L.) Terhadap Kadar Glukosa Darah Dan Gambaran Histologi Hati Tikus (Rattus Norvegicus) Yang Diinduksi Aloksan. Skripsi. Malang: Jurusan Kimia Fakultas Sains Dan Teknologi Universitas Islam Negeri Maulana Malik Ibrahim Malang.

18. Hasanah, U. (2013). Insulin sebagai Pengatur Kadar Gula Darah. Jurnal Keluarga Sehat Sejahtera Vol.11 (22) Des. 2013 ISSN:1693 1157

19. Husna, M. (2008). Pengaruh Pemberian Minyak Jinten Hitam (Nigella sativa L) terhadap Kadar Glukosa Darah pada Tikus Diabetes akibat Induksi Aloksan. Skripsi. Fakultas Kedokteran Universitas Sebelas Maret

20. Hamdany, A.R.A. (2016). Efek Pemberian Ekstrak Daun Zaitun (Olea europaea L.) Sebagai Terapi Asma Terhadap Kolon Mencit Balb/c.Skripsi. Program Studi Kedokteran dan Ilmu Kesehatan Universitas Islam Negeri Syarif Hidayatullah Jakarta

21. Hashmi, M., Khan, A., Hanif, M., Farooq, U., Perveen, S. (2017). Traditional Uses, Phytochemistry, and Pharmacology of Olea europaea (Olive) 